\title{
BULK TANK SOMATIC CELL COUNT IN MILK SAMPLES FROM STATE OF PARANÁ
}

\author{
Newton Pohl Ribas ${ }^{1}$, Paulo Rossi Junior ${ }^{1}$, Humberto Gonzalo Monardes², Uriel \\ Vinicius Cotarelli Andrade ${ }^{3}$, Altair Antonio Valotto ${ }^{4}$, Daiane Regonato ${ }^{1}$ \\ 1 UFPR \\ 2 McGill University - Canadá \\ 3 FEPAR \\ ${ }^{4}$ APCBRH \\ Correspondência: Newton Pohl Ribas: newtonribas.ufpr@gmail.com
}

\begin{abstract}
This research studied somatic cell count in bulk tank milk samples (BTSCC) from the state of Paraná, Brazil, at the Milk Quality Laboratory of the Dairy Herd Analysis Service of the Holstein Association of Paraná, the result of technical and scientific cooperation between UFPR and McGill University of Canada. A total of 1,950,034 bulk tank milk samples from ten regions of the state of Paraná were analyzed between January 2005 and April 2012. Fixed effects were the month and year of analysis, region and age of the sample. Means and standard deviations of BTSCC were $553,519 \pm 545,532$ cells $/ \mathrm{ml}$, respectively. All fixed effects were statistically significant $(P<0.01)$. Highest values for BTSCC are observed in the month of February $(554,000 \mathrm{cells} / \mathrm{ml} \pm 1.45)$ and lowest values in September $(450,000 \mathrm{cell} / \mathrm{s} / \mathrm{ml} \pm 1.47)$. Similarly, the highest values were found in the year $2010(567,000 \mathrm{cells} / \mathrm{ml} \pm 1.16)$, the lowest BTSCC was found in $2012(444,000 \mathrm{celll} / \mathrm{ml} \pm 1.57)$. The region effect was also significant with the highest values found in the South Center/ Guarapuava $(668,000 \mathrm{cells} / \mathrm{ml} \pm 0.87)$ and the lowest in the Southwest/ Francisco Beltrão $(359,000 \mathrm{cells} / \mathrm{ml} \pm$ 2.00). Both variables showed a reduction of their values with increasing age of the sample, from $518,000 \pm 1.08$ to $472,000 \mathrm{cells} / \mathrm{ml} \pm 2.14$ between the first and the seventh day, for the BTSCC. Coefficient of variation for BTSCC was $96.10 \%$. The $\mathrm{R}^{2}$ was 0.39 for BTSCC.
\end{abstract}

Key Words: age of the sample; mastitis; month and year of analysis; milk quality; region

\section{CONTAGEM DE CÉLULAS SOMÁTICAS EM AMOSTRAS DE LEITE DE TANQUES NO ESTADO DO PARANÁ}

RESUMO: A presente pesquisa avaliou o comportamento da contagem de células somáticas de leite de tanques (CCST) provenientes do Estado do Paraná, analisadas pelo Laboratório de Análise da Qualidade do Leite do Programa de Análise de Rebanhos Leiteiros do Paraná da Associação Paranaense de Criadores de Bovinos da Raça Holandesa, fruto do convênio entre UFPR e McGill University do Canadá. Analisou-se um arquivo contendo 1.950 .034 amostras de leite de tanques, obtidas no período de janeiro de 2005 a abril de 2012, em dez regiões do Estado. Foram estudados os efeitos de meio, entre eles, mês e ano de análise, região e idade da amostra. As médias estimadas e desvios-padrão para CCST foram $553.519 \pm 545.532$ células/ ml respectivamente. Todos os efeitos incluídos no modelo foram significativos $(P<0,01)$. Ocorreram importantes variações da CCST entre os meses de análise, destacando-se respectivamente as maiores médias e seus erros-padrão para o mês de fevereiro (554.000 células/ $\mathrm{ml} \pm 1,45)$ e as menores para o mês setembro (450.000 células/ $\mathrm{ml} \pm 1,47)$. Da mesma forma, o ano de análise apresentou variações significativas, em que as maiores médias ocorreram no ano de 2010 (567.000 células/ $\mathrm{ml} \pm 1,16$ ) e as menores em 2012 (444.000 células/ $\mathrm{ml} \pm 1,57$ ). Para as regiões, as maiores médias e seus errospadrão foram de 668.000 células/ $\mathrm{ml} \pm 0,87$ (Centro Sul - Guarapuava) e as menores foram de 359.000 células/ $\mathrm{ml} \pm 2,00$ (Sudoeste - Francisco Beltrão). O efeito de idade da amostra, em dias, caracterizou redução da CCST de $518.000 \pm 1,08$ para 472.000 células/ $\mathrm{ml} \pm 2,14$ quando as amostras foram analisadas entre o primeiro e o sétimo dia de idade, para CCST. O coeficiente de variação para CCST foi de $96,10 \%$. O R $\mathrm{R}^{2}$ para a CCST foi de $0,39 \%$.

Palavras-chave: idade da amostra; mastite; intervalo de análise; qualidade do leite; região 


\section{INTRODUCTION}

The somatic cell count (SCC) is an established evaluation parameter used by programs that monitor udder health, milk quality improvement and payment for quality in traditional producer countries. (Schukken et al., 1993, Godkin, 2000, Fonseca, 2001).

The SCC has been widely used in developed countries since electronic devices made this practice available to producers (Fonseca and Santos, 2000; Santos, 2001 and Godking, 2000) In Brazil, it was introduced in 1991 by the Milk Quality Laboratory of the Dairy Herd Program Analysis of Paraná, from the Holstein Association of Paraná (APCBRH), Curitiba-PR. It was the result of technical and scientific cooperation between Universidade Federal do Paraná (UFPR) and McGill University in Canada.

The SCC has been used by industries as payment criteria for milk quality, making it a tool for management and quality monitoring, being directly related to programs to reduce production losses and to opportunities for milk higher pay (Harmon and Reneau, 1993, Rysanek and Babak, 2005).

High bulk tank somatic cell count (BTSCC) affects the composition of milk, the products shelf life, causing significant losses to dairy industry (Monardes, 1998).

According to Harmon \& Reneau (1993), there is a significant association between BTSCC with the limit of $1,500,000$ cells $/ \mathrm{ml}$. The percentage of infected udder quarters could reach up to $48 \%$ and the losses of milk yield up to $29 \%$.

According to Dürr et al. (2011), databases of herds' production performance are essential tools to the rational management of animals, to genetic evaluation of dairy cattle, to traceability programs of animals and milk products and to the dairy chain strategic planning.

The Milk Quality Laboratory of the Dairy Herd Program Analysis of Paraná of APCBRH provide services to monitor milk quality in compliance with National Program for Improvement of Quality Milk (PNMQL) through the Normative proceeding IN 51 (Brazil, 2002) and 62 (Brazil, 2011) of the Ministry of Agriculture, Livestock and Supply (MAPA). This work analyzed the BTSCC samples from dairy industries under its services.

This research objective was to evaluate how environment effects (month and year of analysis, and the region and age of the sample) could influence the BTSCC.

\section{MATERIAL AND METHODS}

There were used 1,950,034 bulk tank milk samples from production sites located in 10 regions, and respective main city, in the state of Paraná (PR). They were analyzed from January 2005 to April 2012.

The bulk tank milk samples were collected monthly by personnel trained by the dairy industry, before collecting the bulk tank milk is homogenized to analyze maintained in a sterilized jar that uses the default Bronopol, according to the procedures recommended by the manuals of Field Operations (Horst, 2008), and Sample Collection (Horst, 2010) of the Milk Quality Laboratory. The samples were placed in standard vials $(70 \mathrm{ml})$, using the preservative bronopol (2-bromo-2-nitro propane-1,3diol) and sent to Milk Quality Laboratory localized in Associação Paranaense de Criadores de Bovinos da Raçã Holandesa, Curitiba - PR - Brazil.

The number of days elapsed between the farm milk collection and the analysis in the laboratory, Curitiba-PR, was defined as the age of the sample. The milk samples were analyzed for 
BTSCC, using equipment Somacount $500 \AA$, by flow cytometry.

The BTSCC data was prepared from the original Milk Quality Laboratory database to achieve better accuracy: BTSCC values equal to zero or negative as well as greater than $4,525,000$ cells $/ \mathrm{ml}$ were not considered. The same was valid for age of the sample lower than 1 and greater than 7 days.

All the database preparation, data pre-sorting and statistical analysis for BTSCC values were performed in the Department of Animal Science of the SCA of the UFPR in Curitiba-PR.

All data were analyzed through computer software SAS® version 9.3. Studied traits were analyzed through the following mathematical model:

Where:

$$
Y_{i j k l}=\mu+M_{i}+A_{j}+R_{k}+I_{1}+e_{i j k l}
$$

$Y_{\mathrm{ijkl}}=$ BTSCC values, collected in month $\boldsymbol{i}$, year $\boldsymbol{j}$, region $\boldsymbol{k}$, with age of the sample $I$ and associated random error of each observation $\mathrm{e}_{\mathrm{ijkl}}$.

$\mu \quad=$ general average;

$\mathrm{M}_{\mathrm{i}} \quad=$ effects of month of analyzes $\boldsymbol{i}$, being $\boldsymbol{i}=1$ (Jan.), 2 (Feb.), ... 12 (Dec.);

$A_{j}=$ effects of year of analyzes $\boldsymbol{j}$, being $\boldsymbol{j}=2005,2006, \ldots$ 2012*;

$R_{k}=$ effects of the region $k$, being $\boldsymbol{k}=1,2, . ., 10$;

$l_{1}=$ effects of the age of the sample in days $I$, being $I=1,2, \ldots 7$;

$\mathrm{e}_{\mathrm{ijkl}}=$ associated random error of each observation $\mathrm{Y}_{\mathrm{ijk}}$.

${ }^{*}$ In 2012, there were milk samples collected only from the first four months of the year.

The evaluated dependent variable was BTSCC, as a result of the reading by flow cytometry equipment, Somacount $500 \AA$ (Bentley Instruments, 1995b), in thousand cells $/ \mathrm{ml}$. Comparisons between means were performed using the Tukey test at $1 \%$ probability.

\section{RESULTS AND DISCUSSION}

The estimated mean, its standard deviation and the variation coefficient of BTSCC from the 1,950,034 analyzed samples from 2005 to 2012, were respectively $553,519 \pm 545,532$ cells $/ \mathrm{ml}$ and $96.10 \%$.

The large variability (CV 96.10\%) in the BTSCC values is characterized by the standard deviation similar to the mean. Machado et al. (2000) and Paula et al. (2004) also found the same.

The average BTSCC found in this study is higher than those reported by Franks (2001) and Godkin (1999), considering averages of BTSCC in different countries. Franks (2001) observed the lowest average in Switzerland $(112,000 \mathrm{cells} / \mathrm{ml})$ and the highest in Israel $(382,000 \mathrm{cells} / \mathrm{ml})$, and Godkin (1999), in the Province of Ontario, Canada, observed an average of 250,000 cells $/ \mathrm{ml}$.

In Brazil, similar results were obtained by Machado et al. (2000), working with a smaller number of data (4785 samples). They found mean and standard deviation of $505,000 \pm 593,000$ cells $/ \mathrm{ml}$, and Paula et al. (2004) analyzed 257,540 bulk tank somatic cell count in the states of Santa Catarina, Paraná and São Paulo, from 1999 to 2001 , and found an average of 486,812 $\pm 401,547 \mathrm{cells} / \mathrm{ml}$ with a variation coefficient of $62.35 \%$.

According to Harmon \& Reneau (1993), the limit of 500,000 cells $/ \mathrm{ml}$ found in this study would be associated to $16 \%$ of infected udder quarters in herds and to $6 \%$ loss in milk production.

The SCC of milk from a cow indicates quantitatively the mammary gland degree of infection. Thus, SCC of milk from healthy animals is usually lower than 300,000 cells $/ \mathrm{ml}$ (Philpot, 1998b; Machado, Sarríes \& Pereira, 2000; NMC, 2001; Fonseca \& Santos, 2000). 
These results are considered high when compared with those countries with well-developed dairy industry, reflecting carelessness by producers regarding the health of the mammary gland. That seems to be the result of the lack of incentives by milk industries to establish programs to pay for milk quality based on SCC.

In Brazil, since the publication of the MAPA IN 51 (Brazil, 2002), the SCC criteria has been used to promote the improvement of milk quality. According to Fonseca (2001), a survey conducted in 93 dairy plants in the 1998 offseason, only $7 \%$ of the producers used the SCC test.

It is expected that, after the publication of IN 62 (Brazil, 2011), establishing to 2015 new legal limit of 400,000 cells $/ \mathrm{ml}$, industries and producers should give greater attention to SCC and that would decrease over the years. According Monardes (1998), the establishment of legal limits on economic blocks and countries like European Union $(400,000$ cells $/ \mathrm{ml})$, Canada $(500,000$ cells $/ \mathrm{ml})$ and New Zealand $(400,000$ cells $/ \mathrm{ml})$ respectively in 1992, 1994 and 1995 were decisive in enabling public policies for food security.

The results of variance analysis of BTSCC in Paraná are shown in Table 1. All the variables in the mathematical model were significant $(P<0.01)$.

The month of analysis significantly influenced the BTSCC $(P<0.01)$, as can be seen in the summary of the variance analysis (Table 1).

In Table 2, it can be identified higher estimates of adjusted means for BTSCC in summer, which corresponds to the period from January to March (525,000 to 532,000 cells $/ \mathrm{ml}$ ). Moreover, lower estimates were found in late winter and early spring from August to October $(477,000$ to 463,000 cells $/ \mathrm{ml})$. Those results resemble findings from other authors (Harmon \& Reneau, 1993; Harmon, 1998b; Ott et al. 1999;
Pritchard et al. 2001 and Paula et al. 2004).

According to Harmon \& Reneau (1993), Harmon (1998b) and Paula et al. (2004), the stress of high temperatures and humidity, increasing the susceptibility to infection and the number of pathogens to which cows are exposed, make the summer the period with the highest incidence of clinical mastitis, mainly of environmental origin.

Table 2 shows that the months of March and April, June and July, June and November are similar to each other $(P<0.01)$, why in the state of Paraná temperatures in these months are milder and therefore they have no differences significant.

In the summary of the variance analysis (Table 1), it is shown the year of the analysis significantly influenced the variable BTSCC $(P<0.01)$.

Higher estimates of adjusted means (Table 3) were observed in 2010 $(567,000$ cells $/ \mathrm{ml})$ and the lowest in 2012 (444,000 cells/ml). Also, shows that in 2006 and 2007 they were similar (Table 3, $P<0,01$ ).

Several authors have also studied the effect of the years in BTSCC analysis (Schukken et al. 1990; Schukken et al. 1992a; Schukken et al. 1993; Sargeant et al. 1998; Godkin, 1999, and Paula et al ., 2004), showing a reduction in BTSCC over the years, due to the implementation of legal limits, mammary gland health monitoring programs and payment for quality.

\begin{tabular}{|c|c|c|}
\hline \multirow{2}{*}{ SOURCE OF VARIATION } & \multirow{2}{*}{ df } & MEANS SQUARES \\
\hline & & BTSCC ( $(x 1,000$ cells $/ \mathrm{ml})$ \\
\hline Month of analysis & 11 & $1,372,097.84^{\text {t* }}$ \\
\hline Year of analysis & 7 & $3,448,788.21^{\text {t* }}$ \\
\hline Region & 9 & $25,269,272.94^{\star \star}$ \\
\hline Age of sample (days) & 6 & $264,597.45^{\text {t* }}$ \\
\hline Residual & $1,950,000$ & $282,964.74^{\text {t* }}$ \\
\hline $\mathrm{R}^{2}$ & 0.39 & \\
\hline CV (\%) & 96.10 & \\
\hline
\end{tabular}


Table 2 - Number of observations $(\mathrm{N})$, number of observations accumulated $(\%)$ estimates of adjusted means and standard errors by the least squares method of BTSCC, and months of analysis

\begin{tabular}{|c|c|c|c|c|c|}
\hline \multirow{2}{*}{$\begin{array}{l}\text { MONTH OF } \\
\text { ANALYSIS }\end{array}$} & \multirow{2}{*}{$\mathrm{N}$} & \multirow{2}{*}{$\%$} & \multicolumn{3}{|c|}{ BTSCC ( $x 1,000$ cells $/ \mathrm{ml})$} \\
\hline & & & Mean $^{1}$ & \pm & SE \\
\hline January & 165.665 & 8,50 & $525^{\mathrm{a}}$ & \pm & 1,43 \\
\hline February & 161.031 & 16,75 & $554^{\circ}$ & \pm & 1,45 \\
\hline March & 183.159 & 26,15 & $532^{\circ}$ & \pm & 1,36 \\
\hline April & 178.901 & 35,32 & $531^{\infty 0}$ & \pm & 1,37 \\
\hline May & 170.074 & 44,04 & $516^{e}$ & \pm & 1,40 \\
\hline June & 153.014 & 51,89 & $491^{\top}$ & \pm & 1,48 \\
\hline July & 155.888 & 59,88 & $489^{9}$ & \pm & 1,47 \\
\hline August & 157.926 & 67,98 & $477^{n}$ & \pm & 1,45 \\
\hline September & 150.967 & 75,72 & $450^{\prime}$ & \pm & 1,47 \\
\hline October & 159.212 & 83,89 & 463 & \pm & 1,45 \\
\hline November & 156159 & 91,90 & $491^{x}$ & \pm & 1,46 \\
\hline December & 158.038 & 100,00 & $500^{\prime}$ & \pm & 1,46 \\
\hline Total & 1.950 .034 & & & & \\
\hline
\end{tabular}

Table 3 - Number of observations $(\mathrm{N})$, number of observations accumulated (\%) estimates of adjusted means and standard errors by the least squares method of BTSCC, according to the year of analysis

\begin{tabular}{cccccc}
\hline YEAR OF & \multirow{2}{*}{$\mathrm{N}$} & \multirow{4}{c}{ BTSCC $(x 1,000$ cells $/ \mathrm{ml})$} \\
\cline { 4 - 6 } ANALYSIS & & & Mean & \pm & SE \\
\hline 2005 & 125.257 & 6,42 & $459^{\mathrm{a}}$ & \pm & 1,63 \\
2006 & 186.438 & 15,98 & $495^{\circ}$ & \pm & 1,33 \\
2007 & 262.332 & 29,44 & $493^{\circ 0}$ & \pm & 1,16 \\
2008 & 326.385 & 46,17 & $501^{\circ}$ & \pm & 1,07 \\
2009 & 337.243 & 63,47 & $549^{\circ}$ & \pm & 1,08 \\
2010 & 276.463 & 77,65 & $567^{\dagger}$ & \pm & 1,16 \\
2011 & 287.339 & 92,38 & $506^{9}$ & \pm & 1,12 \\
$2012^{2}$ & 148.577 & 100,00 & $444^{n}$ & \pm & 1,57 \\
\hline Total & 1.950 .034 & & & &
\end{tabular}

Tukey Test. Means followed by at least the same letter don't differ statistically from each other

Tukey
$\left.{ }^{2} \mathrm{P}<0.01\right)$
2012 is

In Table 4, it is shown that the region affected significantly $(P<0.01)$ the characteristic studied (BTSCC).

The adjusted means and standard errors for the ten regions and their main cities are described in Table 4. The lowest BTSCC estimates were 359,000 cells $/ \mathrm{ml}$ for the Southwest region, Francisco Beltrão - PR and highest 668,000 cells $/ \mathrm{ml}$ for the Center South, Guarapuava - PR.

In table 4, the higher BTSCC means are represented by the regions of Center South, Guarapuava - PR; Metropolitan Curitiba - PR and Southeast, Irati - PR, with 668, 620 and 573 (x 1000 cells $/ \mathrm{ml})$ respectively.
These regions, according to the Köppen classification (IAPAR, 1999), show temperate climate type Cfb, with average temperature in the coldest month between $15^{\circ} \mathrm{C}$ and $18^{\circ} \mathrm{C}$, cool summers with average temperature in the warmest month below $22^{\circ} \mathrm{C}$, without dry season and annual relative humidity ranging from 70 to $85 \%$.

The BTSCC averages on Northwest regions, Umuarama - PR and Center East, Ponta Grossa - PR were similar (Table 4, $\mathrm{P}<0,01$ ).

Ott et al. (1999) and Norman et al. (2001) obtained similar results in the United States. They found significant differences between regions in the BTSCC study, more likely caused by differences in weather: dry climate regions had lower BTSCC and hot and humid climate higher.

Emanuelson \& Funke (1991); Allore et al. (1997); Wells \& Ott (1998); Ott et al. (1999) and Norman et al. (2001) found differences between regions, ascribed by the level of technology, production and herd size.

In Brazil, Noro (2004) and Paula et al. (2004) found similar results to this study, highlighting the differences found in herd size, production system, level of technology adopted, implementation of mammary gland health control programs and milk quality payment, stimulated by the dairy industries of those regions.

In the variance analysis summary (Table 1), it is shown that the age of the sample significantly influenced the BTSCC $(P<0.01)$. These results contrast with those obtained by Monardes et al. (1996), who found no significant effect of the sample age on the SCC. 


\begin{tabular}{|c|c|c|c|c|c|}
\hline \multirow{2}{*}{$\begin{array}{c}\text { Table } 4 \begin{array}{r}\text { - Number } \\
\text { estimates } \\
\text { method of }\end{array} \\
\text { REGION } \\
\text { MUNICIPAUTY }\end{array}$} & \multirow{2}{*}{$\mathrm{N}$} & \multirow{2}{*}{$\%$} & \multicolumn{3}{|c|}{$\operatorname{BTSCC}(x 1,000$ cells $/ \mathrm{ml})$} \\
\hline & & & \multirow{2}{*}{$\begin{array}{c}\text { Mean' }^{1} \\
442^{\mathrm{a}}\end{array}$} & \multirow{2}{*}{$\begin{array}{l} \pm \\
\pm\end{array}$} & \multirow{2}{*}{$\begin{array}{c}\text { SE } \\
2,18\end{array}$} \\
\hline $\begin{array}{l}\text { 1. Northwest } \\
\text { Umuarama }\end{array}$ & 61.991 & 3,18 & & & \\
\hline $\begin{array}{l}\text { 1. Central West } \\
\text { Campo Mourão }\end{array}$ & 414.991 & 24,46 & $405^{\circ}$ & \pm & 0,85 \\
\hline $\begin{array}{l}\text { 2. Central North } \\
\text { Londrina }\end{array}$ & 145.630 & 31,93 & $520^{\circ}$ & \pm & 1,46 \\
\hline $\begin{array}{l}\text { 3. Pioneer North } \\
\text { Cornélio Procópio }\end{array}$ & 35.372 & 33,74 & $533^{\circ}$ & \pm & 2,85 \\
\hline $\begin{array}{l}\text { 4. Central East } \\
\text { Ponta Grossa }\end{array}$ & 138.721 & 40,86 & $435^{3 e}$ & \pm & 1,50 \\
\hline $\begin{array}{l}\text { 5. West } \\
\text { Cascavel }\end{array}$ & 135.252 & 47,79 & $461^{\circ}$ & \pm & 1,50 \\
\hline $\begin{array}{l}\text { 6. Southwest } \\
\text { Francisco Beltrão }\end{array}$ & 73.903 & 51,58 & $359^{9}$ & \pm & 2,00 \\
\hline $\begin{array}{l}\text { 7. Center South } \\
\text { Guarapuava }\end{array}$ & 502.468 & 77,35 & $668^{n}$ & \pm & 0,87 \\
\hline $\begin{array}{l}\text { 8. Southeast } \\
\text { Irati }\end{array}$ & 51.142 & 79,97 & $573^{1}$ & \pm & 2,40 \\
\hline 10. Curitiba & 390.564 & 100,00 & $620^{\mathrm{J}}$ & \pm & 0,94 \\
\hline Total & 1.950 .034 & & & & \\
\hline
\end{tabular}

Table 5 presents the adjusted means for BTSCC that show similar values for two and three days, as four, five and six days are similar to each other $(P<0.01)$.

However, as a tendency, when the age of the sample increased from 1 day to 7 days the BTSCC decreased from 518 to 472 (x 1000 cells $/ \mathrm{ml})$.

Paula et al. (2004), found that from the first to the seventh day of age the samples had a reduction in the BTSCC values, contrasting with Kennedy et al. (1982), cited by Ostrensky (1999), who observed that the SCC values in the first three days remained virtually unchanged, and with Ostrensky (1999), who found an increase in the SCC values.

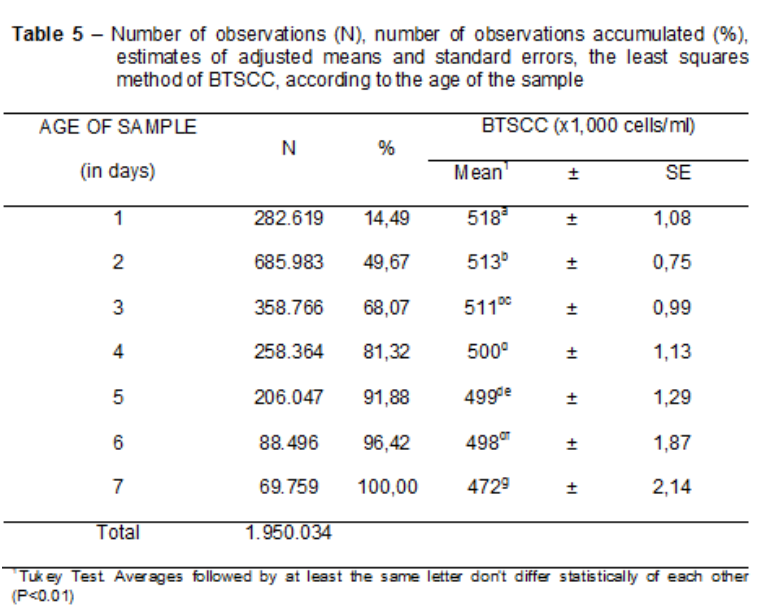

Kennedy et al. (1982), cited by Ostrensky (1999), as in this study, also reported that the SCC was reduced as the age of the sample increased, showing a reduction of $28 \%$ (Ostrensky, 1999).

Table 5 shows that $68.07 \%$ of the samples were analyzed by the third day, while $96.42 \%$ until the sixth day. Monardes et al. (1996) reported that in Canada, $93 \%$ of the samples were analyzed by the third day and $99 \%$ by the seventh day after collection.

\section{CONCLUSION}

The averages for BTSCC in the State of Paraná are high compared to countries with well-developed dairy industry, reflecting a high level of mastitis in the studied herds associated with a significant amount of infected udder quarters that would lead to significant milk losses. Based on the results found in this study, it is suggested a demand for producers to reassess the management of mastitis control programs that would focus on the health of the mammary gland. The dairy industries must also reevaluate its payment programs for milk quality, correlating BTSCC with the reduction on production losses and improving opportunities for larger returns on milk production. The new legal limit to be implemented, as an instrument of public policy in favor of food security, should 
signal that Brazil can compete in the dairy products international market. It would show that the milk quality, internally, also follows standards established for over 30 years by traditional producing countries.

\section{ACKNOWLEDGMENTS}

To the Milk Quality Laboratory of the Dairy Herd Analysis Program (PARLPR), of the Parana Holstein Breeders Association (APCBRH), which is the result of technical and scientific cooperation between UFPR and McGill University in Canada, for making available the database and for their valuable collaboration to this study.

To FUNDO PARANÁ of the Secretaria da Ciência, Tecnologia e Ensino Superior, Curitiba-PR, this research was funded through the covenants numbers $01 / 07$ and 19/07 of the Foundation of the Federal University of Paraná for the Development of Science, Technology and Culture.

\section{INFORMATIVE NOTES}

The research project was approved (protocol 024/2011) by the Ethics Committee on Animal Use (CEUA), Sector of Agricultural Sciences (CAS) of UFPR.

\section{REFERENCES}

ALLORE, H. G.; OLTENACU, P. A.; ERB, H. N. Effects of season, herd size, and geographic region on the composition and quality of milk in the Northeast. Journal of Dairy Science, Champaign, v. 80, n.11, p.3040-3049, 1997.

BENTLEY INSTRUMENTS. 1995b. Somacount 300 Operator's Manual. Chaska. p.12.

BRASIL. Ministério da Agricultura e do Abastecimento. Aprova os regulamentos técnicos de produção, identidade e quantidade do leite tipo A, do leite tipo B, do leite tipo $C$, do leite pasteurizado e do leite cru refrigerado e o regulamento técnico da coleta de leite cru refrigerado e seu transporte a granel, em conformidade com os anexos a esta Instrução Normativa. Portaria n. 51, de 18 de setembro de 2002. Diário Oficial da República Federativa do Brasil, Brasília, DF, n.321, 20 set. 2002.

BRASIL. Ministério da Agricultura e do Abastecimento. Altera a Instrução Normativa n. $51 / 2002$. Estabelece novos prazos e limites para a redução de CBT e CCS até o ano de 2016, chegando aos valores de $100 \mathrm{mil} / \mathrm{ml}$ e 400 $\mathrm{mil} / \mathrm{ml}$, respectivamente. Suprime os Regulamentos Técnicos de Identidade e Qualidade dos leites tipos "B" e "C". Portaria n. 62 , de 30 de dezembro de 2011. Diário Oficial da República Federativa do Brasil, Brasília, DF, n.251, 30 dez. 2011.

DURR, J. W.; RIBAS, N. P.; COSTA,C. N.et al. Milk recording as an indispensable procedure to assure Milk quality. Revista Brasileira de Zootecnia, Viçosa, v.40, p.76-81, 2011.

EMANUELSON, U.; FUNKE, H. Effect of milk yield on relationship between bulk milk somatic cell count and prevalence of mastitis. Journal of Dairy Science, Champaign, v.74, n.8, p.24792483, 1991.

FONSECA, L. F. L.; SANTOS, M. V. Qualidade do leite e controle de mastite. São Paulo: Lemos editorial, 2000.

FONSECA, L. F. L. Pagamento por qualidade: situação atual e perspectivas para o Brasil. In: SIMPÓSIO INTERNACIONAL SOBRE PRODUÇÃO INTENSIVA DE LEITE, 5., 2001, Belo Horizonte. Anais... Belo Horizonte, 2001. p. 17-29.

FRANKS, B. International Milk quality. 2001. Available in:

<http://www.2nzdairy.co.nz:82/suppliernews/july 2001.pdf>. Access: 03/24/2012.

GODKIN, A. Monitoring and controlling mastitis: progress in Ontario. In: NATIONAL MASTITIS COUNCIL REGIONAL MEETING, 1999, Waterloo. Proceddings... Madison: National Mastitis Council, 1999. p. 1-9.

GODKIN, A. Qualidade do leite ao redor do mundo: o papel da CCS. In: SIMPÓSIO INTERNACIONAL SOBRE QUALIDADE DO LEITE, 2., 2000, Curitiba. Anais... Curitiba, 2000. p. 9-20.

HARMON, R. J.; RENEAU, J. K. Factors affecting somatic cell counts in milk. In: NATIONAL MASTITIS COUNCIL ANNUAL 
MEETING, 32., 1993, Arlington. Proceedings... Madison: National Mastitis Council, 1993. p. 4857.

HARMON, R. J. Aspectos econômicos da mastite bovina. In: SIMPÓSIO

INTERNACIONAL SOBRE QUALIDADE DO LEITE, 1., 1998, Curitiba. Anais... Curitiba, 1998a. p. 36-39.

HARMON, R. J. Somatic cell counts: Mysths vs reality. In: NATIONAL MASTITIS COUNCIL REGIONAL MEETING, 37., 1998, Bellevue. Proceedings... Madison: National Mastitis Council, 1998b. p. 40-50.

\section{HORST, J. A. Manual de Operações de} Campo. Curitiba: Programa de Análise de Rebanhos Leiteiros do Paraná - APCBRH, 2008.

HORST, J. A. Manual de Coleta de Amostras: Componentes e CCS. Curitiba: Programa de Análise de Rebanhos Leiteiros do Paraná APCBRH, 2010.

\section{INSTITUTO AGRONOMICO DO PARANÁ (IAPAR). Cartas climáticas do Paraná. Londrina: IAPAR, 1999.}

KENNEDY, B. W.; SETHAR, M. S.; TONG, A. K. $W$. et al. Environmental factors influencing testday somatic cell counts in Holsteins. Journal of Dairy Science, Champaign, v.65, n.2, p.275280, 1982.

LIMA, M. C. G.; SENA, M. J.; MOTA, R. A. et al. Contagem de células somáticas e análises físico-químicas e microbiológicas do leite cru tipo $C$ produzido na região Agreste do Estado de Pernambuco. Arquivos do Instituto Biológico, São Paulo, v.73, n.1, p.89-95, jan./mar. 2006.

MACHADO, P. F.; PEREIRA, A. R.; SARRÍES, G. A. Composição do leite de tanques de rebanhos brasileiros distribuídos segundo sua contagem de células somáticas. Revista Brasileira de Zootecnia, Viçosa, v.29, n 6, p.1883-1886, 2000.

MONARDES, H. G.; MOORE, R. K.; CORRIGAN, B.; RIOUX, Y. Milk preservatives under different systems of samples storage in Quebec, Canada. Journal of Food. Protection, Des Moines, v.59, n.2, p.151-154, 1996.

MONARDES, H. Programa de pagamento de leite por qualidade em Québec, Canadá. In: SIMPÓSIO INTERNACIONAL SOBRE QUALIDADE DO LEITE, 1., 1998, Curitiba. Anais... Curitiba, 1998. p. 40-43.
NATIONAL MASTITIS COUNCIL (NMC). Guidelines on normal and abnormal raw milk based on somatic cell counts and sings of clinical mastitis. 2001. Available in: <http://www.nmconline.org/docs/abnmilk.pdf>. Access: 07/21/2012.

NORMAN, H. D.; MILLER, R. H.; WRIGHT, J. R.; WIGGANS, G. R. Herd and state means for somatic cell count for dairy herd improvement. 2001. Available in: <http://www.nalusda.gov/ttic/tektran/data/000010 6436.html>. Access: 06/03/2012.

NORO, G. Fatores ambientais que afetam a produção e a qualidade do leite em rebanhos ligados a cooperativas gaúchas. $92 \mathrm{p}$. Dissertação (Mestrado em Ciências Veterinárias) - Universidade Federal do Rio Grande do Sul, Porto Alegre, 2004.

OSTRENSKY, A. Efeitos de ambientes sobre a contagem de células somáticas no leite de vacas da raça holandesa no Paraná. $114 \mathrm{f}$.

Dissertação (Mestrado em Ciências Veterinárias) - Curso de Pós-Graduação em Ciências Veterinárias, Setor de Ciências Agrárias, Universidade Federal do Paraná, Curitiba, 1999.

OTT, S. L.; WELLS, S. J.; SMITH, M. A. Bulk tank somatic cell counts of U.S. Milk supply, 1997. In: NATIONAL MASTITIS COUNCIL ANNUAL MEETING, 38., 1999, Arlington. Proceedings... Madison: National Mastitis Council, 1999. p.154-156.

PAULA, M. C.; RIBAS, N. P.; MONARDES, H. G. et al. Contagem de Células Somáticas em Amostras de Leite. Revista Brasileira de Zootecnia, Viçosa, v.33, n.5, p.1303-1308, 2004.

PETERS, M. D. P.; HONORATO, L. A.; GONÇALVES, B. P. et al. Incidência e composição do leite com instabilidade da caseína e leite mastítico. In: CONGRESSO DE INICIAÇÃO CIENTÍFICA, 18., 2009, Pelotas; ENCONTRO DE PÓS-GRADUAÇÃO, 11., 2009, Pelotas. Anais... Available in: <http://www.ufpel.edu.br/cic/2009/cd/pdf/CA/CA _00445.pdf>. Access:04/13/2012.

PHILPOT, W. N. Importância da contagem de células somáticas e outros fatores que afetam a qualidade do leite. In: SIMPÓSIO INTERNACIONAL SOBRE QUALIDADE DO LEITE, 1., 1998, Curitiba. Anais... Curitiba, 1998b. p. 28-35. 
PRITCHARD, D. E.; ANDERSON, K. L.; MYERS, Z. H. Seasonal patterns of bulk tank milk somatic cell counts. 2001. Available in: $<$ http://www.cals.ncsu.edu/na_sci/extension/dair y/winter\%202000\%20word\%2oversion\%202.htm >. Access:08/03/2012.

RUEGG, P. L. Relationship between bulk tank Milk somatic cell count and antibiotic residues. In: NATIONAL MASTITIS COUNCIL ANNUAL MEETING, 44, 2005, Orlando. Proceedings... Madison: National Mastitis Council, 2005. p. 2835.

RYSANEK, D.; BABAK, V. Bulk tank Milk somatic cell count as an indicator of the hygiene status of primary Milk production. Journal of

Dairy Research, Cambridge, v.72, p.1-6, 2005.

SANTOS, M. V. Contagem de células somáticas e qualidade do leite e derivados. In: SIMPÓSIO INTERNACIONAL SOBRE PRODUÇÃO INTENSIVA DE LEITE, 5., 2001, Belo Horizonte. Anais... Belo Horizonte, 2001. p. 115-127.

SARGEANT, J. M.; SCHUKKEN, Y. H.; LESLIE, K. E. Ontario bulk milk somatic cell count reduction program: progress and outlook. Journal of Dairy Science, Champaign, v. 81, n. 6, p. 1545-1554, 1998.

SCHUKKEN, Y. H.; BUURMAN, J.; BRAND, A. et al. Our industry today: population Dynamics of bulk Milk somatic cell counts. Journal of Dairy Science, Champaign, v.73, n. 5, p.13431350, 1990.

SCHUKKEN, Y. H.; LESLIE, K. E.; WEERSINK, A. J.; MARTIN, S. W. Ontario bulk milk somatic cell reduction program. 1. Impact on somatic cell counts and milk quality. Journal of Dairy

Science, Champaign, v.75, n.12, p.3352-3358, $1992 a$.

SCHUKKEN, Y. H.; LESLIE, K. E.; WEERSINK, A. J.; MARTIN, S. W. Ontario bulk milk somatic cell reduction program. 2. Dynamics of bulk milk somatic cell counts. Journal of Dairy Science, Champaign, v.75, n.12, p.3359-3366, 1992b.

SCHUKKEN, Y. H.; WEERSINK, A.; LESLIE, K. E.; MARTIN, S. W. Dynamics and regulation of bulk milk somatic cell counts. Canadian Journal of Veterinary Research, Ottawa, v.57, p.131135, 1993.

WELLS, S. J.; OTT, S. L. What is the current milk quality in the US? In: NATIONAL MASTITIS COUNCIL ANNUAL MEETING, 37., 1998, St.
Louis. Proceedings... Madison: National Mastitis Council, 1998. p. 10-18. 